\title{
WATER QUALITY MONITORING AFTER FLOODS
}

\author{
Nemanja Kneževićc ${ }^{11}$, Srboljub Nikolic ${ }^{12}$ \\ Pregledni rad (Review article) \\ doi: 10.5937/OdrRaz2101047K \\ UDK: 628.1/.3:658.562 \\ 556.166
}

\begin{abstract}
Safe drinking water is one of the most important conditions for a healthy life. However, in case of disasters and emergencies, the water is often contaminated with various impurities of physical, chemical and / or biological origin. These contaminations can lead to a number of health problems, including various infectious diseases.For that reason, it is important to act preventively, and to perform appropriate treatment and water purification in a timely and urgent manner, depending on the type of pollution.In order to determine the type of pollutionand perform the appropriate water treatment, the precondition is arranging certain chemical analyzes and monitoring of water quality through quality parameters. Since our time and economic resources are limited in the first moments of the accident, it is not possible to monitor all the parameters, so we monitor the most important: $p H$ value, amount of residual chlorine, color, turbidity and the presence of pathogens.However, even when the type of pollution is determined, it is sometimes not possible to do centralized water purification immediately. Therefore, it is important to know the methods that can independently, and with the help of some handy tools, be applied in our household (eg. disinfection by boiling water or using some of the chemicals for disinfection; sedimentation, etc.). Using these methods, at least a physiological minimum can be provided for family members in the first moments after the accident, until a centralized purification is performed.
\end{abstract}

Key words: water, water pollution, floods, monitoring, water treatment.

\section{Introduction}

Water is the source of life, a precious source of health and a necessary condition for human survival. Life originated in water and exists thanks to water.Water is the basic principle and model of everything that exists, the source from which everything originated and to which everything returns.

${ }^{11}$ Nemanja Knezevic, M.A. Faculty of Agriculture, University of Belgrade, R. Serbia

12 Srboljub Nikolic, Ph.D., Assistant Professor, Military Academy, University of Defense, Belgrade, R. Serbia, e-mail: srboljub.nikolic@yahoo.com 
Where there is no water, there is no life.This is the first need of a man, which must be provided permanently.People use water for drinking, food preparation, maintaining hygiene, in agriculture, industry. It is the most abundant substance in the human body.

As a basic means for human life and health, water has become one of the most interesting and most studied substances.Nowadays, the problem of providing sufficient amounts of water for human and other needs is given special attentiongreat mental and material efforts are invested. The amount of clean water is constantly decreasing, and it is consumed where it is necessary, but also where it should not be consumed.

Water is a condition of life on Earth: all vital processes that take place in the biosphere are in some connection with it.It has a role in the metabolism of the body, maintaining hygiene, food production etc.On the other hand, water often endangers man, his goods and the environment: it is often a carrier of severe infections, more or less dangerous chemicals, carcinogenic, radioactive and other substances. That is why more and more work is being done to protect drinking waterfrom all forms of pollution. One of these possible ways of water pollution is flooding.

Floods are one of the most harmful phenomena of all natural disasters:they damage people and infrastructure.Water distribution systems are particularly exposed to floods, as water treatment facilities are mostly located along rivers.Also, water from groundwater systems, wells, streams, rivers or lakes can be polluted in this way as well.

In order to determine the impact of flooding on drinking water, microbiological and physico-chemical analysis of drinking water is performed, becauset the only way to determine if water has of appropriate drinking quality is to perform a

test.During and after the flood, before the use of potentially polluted water (in endangered areas), the appropriate parameters are monitored, and then, in order to make it suitable for use, the appropriate treatments are performed.Generally, only certain parameters are monitored after the flood: $\mathrm{pH}$ value, amount of residual chlorine, color, turbidity and the presence of pathogenic organisms.Impurities that can most often contaminate drinking water are: microorganisms, disinfectants, disinfectant products, inorganic chemicals, organic chemicals and radioactive elements.Hygienically unsafe water can lead to the spread of various infectious diseases, to epidemics of some diseases, and even to death.

In Serbian defence logistics system, quartermaster support appears as one of the most important subsystems.It is planned, organized and realized by the 
bodies of the quartermaster's service, and it is implemented in all levels of management, which unequivocally confirms its importance.It is an organized and focused function, which aims to create the most favorable conditions for the life and work of units, efficient use of available reserves and to carry out combat operations.It is realized through the supply of quartermaster's movables, food, water supply, clothing and provision of service activities. One of the most important functions is water supply.

In order for people to be able to satisfy their vital need for water, it is necessary to establish some kind of water supply both in peace and in emergency and war conditions.

Water supply of the army is an important element of logistical support and represents an uninterrupted process and a constant task of units and institutions of the Serbian Army.

The Quartermaster's Service's obligation is to provide uninterrupted and timely provision of units of Serbian Army with water, regardless of the conditions in which it is performed.

The purpose of this article is to point out the importance of monitoring the quality of water after floods by the competent authorities, but also to raise awareness of individuals that in situations where there is a possibility that water is polluted can take urgent measures in their household to purify water and make it usable for a drink.

The first part will present the most important parameters of water quality that are monitored after emergencies, while the second part will describe the methods for water purification that can be applied in the household.

\section{The most important water parameters monitored after the flood}

"Any sudden or extreme change in water and flowquality,or hydrological and meteorological conditions, should raise suspicions that drinking water is probably to be contaminated for use and water supply." (Marinovic, 2014).Polluted water is the one that has changed its original composition, so that certain substances have been introduced which, by their presence, cause a change in the physical, chemical and biological composition of the water.Increased pollution of water and water facilities during floods is most often caused by: penetration into water facilities by surface water, which, in such cases, is significantly more polluted,penetration of atmospheric water into water facilities and rising groundwater levels, which are almost regularly in when that happens, abruptly feeds on surface and atmospheric waters, which greatly increases the degree of groundwater pollution (Seman, 1987). For this 
reason, it is very important to perform certain chemical analyzes and water quality monitoring both during floods and months after them.

"Water quality is defined by a large number of physical, chemical and biological parameters, as well as the content of organic and inorganic substances, and its testing in recent decades has a global health, economic and legal interest" (Trajkovic, 2016).Water quality can deteriorate significantly during emergencies, especially floods, so it is necessary to constantly monitor water parameters because the number of potential pollutants has increased significantly in that period.Water quality monitoring involves monitoring certain parameters that determine water quality. The mission ofwater monitoring is to consider the current state of water and monitor the tendency of changes in that state in time and space.Through these analyzes, data are obtained on the type of pollutants found in water, their composition and specifics. These data serve us to do the appropriate water treatment in time in order to get hygienically correct water, primarily for drinking, but also for the food production, bathing, washing, etc.Hygienically correct drinking water in our country is regulated by the Rulebook on hygienic safety of drinking water and this term implies the fulfillment of all hygienic conditions in terms of organoleptics, quality and quantity, microbiological and radiological properties, which will meet the need for water, while do not endanger health (Rulebook on hygienic safety of drinking water).

Some of the basic parameters that are monitored after the flood, and which will be discussed below, are chemical: $\mathrm{pH}$ value and chlorine content (residual chlorine), physical properties of water: color and turbidity (turbidity is the turbidity of the solution which occurs due to the presence of suspended (small particles) and colloidal particles. The suspended particles absorb the heat of sunlight and the water is heated, which directly affects the reduction of dissolved $\mathrm{O}_{2}$ ), and the bacteriological-biological properties: the presence of pathogenic organisms, as well.In our country, these values are being monitored in accordance with the Rulebook on the hygienic safety of drinking water. Some of the other parameters that are monitored are water temperature, odor, taste, conductivity, hardness, etc.

\section{PH value}

"The $\mathrm{pH}$ value of water is a measure of the relative alkalinity or acidity of water and is defined as the negative logarithm of the hydrogen-ion concentration" (Bates, 1973).In essence, it shows whether a water is acidic, neutral or basic. The acidity of water comes mainly from weak acids, while the basicity comes from carbonates, bicarbonates and hydroxides. 
The $\mathrm{pH}$ scale ranges from 0 (the most acidic solutions) to 14 (the most basic solutions). Distilled water has a $\mathrm{pH}$ value of 7 , and this is considered a neutral value. According to the Rulebook on the hygienic correctness of drinking water, the prescribed $\mathrm{pH}$ value is from 6.8 to 8.5 (Rulebook on the hygienic correctness of drinking water), while, according to the recommendations of the World Health Organization, the optimum $\mathrm{pH}$ value is in the range of 6.5 to 8.5 .

Although the $\mathrm{pH}$ value generally has no direct effect on water quality, control of this value is necessary at all stages of water treatment to ensure satisfactory clarification and disinfection of water.The optimal $\mathrm{pH}$ value of water intended to be chlorinated should range from slightly acidic to a neutral environment.

Although the $\mathrm{pH}$ value generally has no direct effect on water quality, control of this value is necessary at all stages of water treatment to ensure satisfactory clarification and disinfection of water. The optimal $\mathrm{pH}$ value of chlorination water should range from slightly acidic to a neutral environment. For effective disinfection with chlorine, the $\mathrm{pH}$ value must be less than 8 . However, it has been shown that the best disinfection with chlorine is when the $\mathrm{pH}$ value of water is within the limits of a weakly acidic environment (Manojlovic, 1978).

\section{Chlorine content}

In natural waters, dissolved chlorine can not be find. It is detected in purified water, in the form of residual chlorine, since chlorine is used as a disinfectant (Novakovic\& Domazet, 2003).The amount of chlorine added to water is referred as the "dose".Part of that amount of chlorine is destroyed in the reaction with substances in water (organic materials and metals) and that destroyed amount of chlorine is called "demand". The amount of chlorine that remains is denoted by the term "residual chlorine", and it consists of two manifestations(Ostojić et al, 2014):

a combination of residual chlorine or bound available chlorine (not available for disinfection);

2. free residual chlorine or free available chlorine - is a parameter of water quality because it participates in the disinfection process and guarantees the bacteriological correctness of water.

According to the Rulebook on the hygienic correctness of drinking water, the maximum allowed concentration of total chlorine, as a disinfectant, is up to 3 $\mathrm{mg} / 1$, and of free residual chlorine up to $0.5 \mathrm{mg} / 1$. The problem with the Rulebook is that the lower limit of free residual chlorine is not defined, so even if we do not detect it by testing the water, the water will still be considered correct.It is very important to be careful when determining the 
dose, because if significantly higher amounts of chlorine are present in drinking water than allowed, poisoning can occur (Knezevic \& Ilic, 2000).It is very important to be careful when determining the dose, because if significantly higher amounts of chlorine are present in drinking water than allowed, poisoning can occur (Knezevic \& Ilic, 2000).

\section{Water color}

Color is an optical property of water and occurs due to the presence of colored organic (most often) and inorganic substances (Novakovic\& Domazet, 2003).Color, as a parameter, does not belong to the parameters of toxicity, as well as turbidity, but it is on the list of the American Environmental Protection Agency of secondary (aesthetic) parameters and affects the appearance, and sometimes the smell of water (EPA, 2019).According to the Rulebook on the hygienic correctness of drinking water, the maximum allowed color value of 5 degrees of cobalt-platinum scale is prescribed.In emergencies, such as floods, this value reaches 50 degrees Cobalt-platinum scale. Ideally, drinking water has no visible color.

\section{Waterturbidity}

Turbidity of the water gives the water opacity. Turbidity is a consequence of the presence of suspended particles and colloidal matter (Novakovic\& Domazet, 2003). The turbidity of water is a consequence of the presence of insoluble substances, and it differs from the color of water (which the water is often mixedwith).Water turbidity in distribution systems can occur as a result of disturbance of sediments and biofilm, but also from the penetration of dirty water outside the system.

Like color, turbidity, by itself, may not have health effects, but it can interfere with the disinfection process. However, if there is turbidity in the water, it may potentially contain microorganisms that lead to certain diseases. Also,consumers generally refuse to drink water that does not have the appropriate organoleptic properties - they avoid colored and trubid water.

"Water transparency / turbidity is defined as: clear, almost clear, slightly clear, trubid, very trubid, opaque" (Novakovic\& Domazet, 2003).Turbidity is measured with Nephelometric Turbidity Units (NTUs), to ensure disinfection efficiency, turbidity should not be greater than 1 NTU and preferably much lower. The Rulebook on the hygienic correctness of drinking water prescribes that the maximum permitted value of turbidity is up to 1 NTU (Rulebook on the hygienic correctness of drinking water). 


\section{Biological-bacteriological properties - pathogenic microorganisms}

Water is one of the most common sources and carriers of infectious diseases, especially during and after floods.Contaminated water can serve as a mechanism for the transmission of infectious diseases such as diarrhea, cholera, dysentery or typhus, so it is very important to monitor microbiological indicators (Kayaga \& Reed, 2013). Microbiological quality indicators, according to the Rulebook on the hygienic safety of drinking water can be (Novakovic \& Domazet, 2003):

- total coliform bacteria;

- coliform bacteria of fecal origin;

- total number of aerobic mesophilic bacteria;

- streptococci of fecal origin;

- sulfite-reducing clostridia;

- intestinal protozoa and helminths and their developmental forms

Coliform bacteria

"The content of bacteria in drinking water is the most important sanitary (hygienic) indicator of water quality. Water can be polluted by pathogenic and other microorganisms through fecal pollution of human and animal origin "(Ibid, p. 69).According to the valid Rulebook on the hygienic correctness of drinking water, drinking water must not contain coliform bacteria among other microorganisms, and they are the most suitable group of bacteria for assessing the hygienic correctness of water.Testing of the biologicalbacteriological properties of drinking water after the flood needs to be done as soon as possible, in order to perform the treatment on time, if we test all the bacteria present, it will take a lot of time and resources.Therefore, it is relatively simple and not expensive to test for coliform bacteria.Coliform bacteria are found in faeces and are present in the environment, include organisms that can survive and grow in water, and therefore their presence in drinking water shows only the potential presence of pathogenic microorganisms (water may or may not be contaminated) (WHO , 2017). Coliform bacteria of fecal origin are a subgroup of total coliform bacteria and their presence in drinking water often indicates that recent fecal contamination has occurred and is a more accurate indicator of fecal contamination. The most important representative of these bacteria is Escherichia coli, and, if it is present, we can say with certainty that fecal contamination of drinking water has occurred. 


\section{Other water quality parameters}

Water temperature is an organoleptic property. It affects a number of inorganic ingredients and chemical contaminants that can affect the taste of water. As the temperature of the water increases, the speed of chemical reactions increases, because of which the amount of dissolved gases decreases, which leads to an increase in microorganisms in that water.Previously, it was considered that the most suitable water temperature was from 8 to $12^{\circ} \mathrm{C}$, while the current Rulebook on the hygienic safety of drinking water prescribes that drinking water should have a temperature equal to or lower than the temperature of the source.

The smell and taste of natural water come from microorganisms, dissolved minerals, dissolved gases, and organic matter. Hygienically correct, nonchlorinated water should be odorless and tasteless. However, we must emphasize that smell and taste are correlated with temperature: the higher the temperature is, the better the taste and smell are felt.

The hardness of water comes from the high content of carbonates, hydrocarbons, chlorides, calcium sulfates and magnesium. Water hardness can be reduced by heating water.

Biological oxygen demand (BOD) is the amount of oxygen required by microorganisms in a water sample to oxidize organic matter under aerobic conditions at a temperature of $20^{\circ} \mathrm{C}$.

Water conductivity is an electrical property of water. It is a measure of the total amount of dissolved salts or ions in water. Depending on the concentration of ions, water and aqueous solutions can conduct electricity.

\section{Water treatment during and after floods}

During emergencies, one of the necessary conditions for the protection of the health of the population is to provide access to sufficient quantities of hygienically correct water.Therefore, it is recommended to perform adequate water treatment in order to eliminate all substances that could potentially endanger its quality. Many pathogenic organisms and viruses may be more resistant to treatment, so that in the months after the flood there is a risk of different types of diseases, so it is important to monitor all the parameters for a longer period of time and perform treatment in accordance with the results.

The preparation of drinking water is a set of complex physical, chemical and biological processes of water processing (Jusic, 2016). In the treatment of drinking water, the following basic methods are used (Novakovic\& Domazet, 2003): 
- deposition;

- coagulation and flocculation;

- filtration;

- disinfection.

In addition to these basic ones, some special methods are often used, such as: mixing and aeration, flotation, oxidation, deodorization, softening, etc. "By combining processes and operations, the removal of undesirable substances from raw water is achieved" (Ibid).

In the continuation of the work, we will be based on methods that an individual can apply independently, in order to provide hygienically correct drinking water and food preparation in the first moments, since water treatment at the place of use is much faster than centralized treatment. The treatment of water at the place of use in relation to the centralized one has certain advantages and disadvantages, it is much faster and cheaper, which is important in the first moments. However, unlike centralized treatment, it is much more difficult to control. Another disadvantage of these methods is that they remove physical and microbiological pollution, but not chemical contaminants.

\section{Methods for household water purification}

Household water treatment includes any activity that improves water quality, and the activity is a company at the household level.In this way, large amounts of water cannot be provided, but we strive to provide only as much as is necessary for drinking and food preparation (which is about 5 liters per day per person).

In this paper, three methods that are most often used in domestic water purification will be discussed, namely: disinfection, sedimentation and filtration. Which of these methods we choose depends on the location of the accident and the type of emergency. Since our work deals with monitoring the quality of water after floods, we will pay the most attention to disinfection as a method of purification.

Since there are almost no papers in our literature dealing with the topic of water treatment in households, the information that will be presented in this chapter can be found in the guidelines of the World Health Organization (Kayaga \& Reed, 2013) and the International Federation of Red Cross and Red Cross crescent (IFRC, 2008). 


\section{Disinfection}

If the water is clear, but there is a possibility that it is contaminated, it must be disinfected. In households, manual disinfection can be performed in the following three ways:

\section{By boiling;}

2. Solar way;

3. Using certain chemicals (usually chlorine).

Disinfection can often affect the taste of water. By boiling, the taste is lost, the water is heated by solar means, and the use of chemicals can leave a bad taste of water. All these problems can be overcome by simple methods, e.g. aeration (bringing water into close contact with the air, which increases the oxygen content in the water - thus improving the taste and smell of water). It is important to explain to people who apply disinfection at home that a change in the taste of water due to disinfection is a normal occurrence and that they should not stop disinfecting contaminated water.

Boiling - a traditional method of water purification. If done correctly, safe water will be provided to the population who have no other option to provide it. Boiling is effective only if the temperature is high enough and if it boils long enough (about 3 minutes). After boiling, leave the water to cool naturally and protect the container in which the water is from subsequent contamination.This method has both positive and negative aspects. Positive aspects: in this way, all germs that cause infectious diseases will be killed, and boiling water is something that people can do on their own. Negative aspects: high energy consumption, turbidity cannot be reduced, there is no prolonged effect (such as chlorine), due to improper storage, water can become contaminated again.

Solar disinfection - exposing water to sunlight will destroy most diseasecausing germs. The higher the temperature, the more efficient this method will be (although the water temperature should not rise much above $50^{\circ} \mathrm{C}$ ). A simple method: exposing glass water bottles to the sun.Exposure time depends on the season, weather, but also the turbidity of the water. As with boiling, there are positive and negative aspects to solar disinfection: Positive aspects: Most disease-causing bacteria will be destroyed if the water is exposed to the sun long enough and is a simple method and energy efficient. Negative aspects: there is no residual effect, so improper storage can lead to recontamination and requires more time than other methods and sunny weather. 
Chemical Disinfection - There are many chemicals that can disinfect water. Chlorine is most often used to disinfect household water in emergencies. There are several different forms of chlorine for home use: in liquid form, powder and tablets.They differ in size and strength, so different amounts are needed depending on the formulation, and it is always necessary to follow the instructions for use prescribed by the manufacturer. Chemical disinfection is not as effective when working with dirty or trubid water. If the water is trubid, it is necessary to use a double dose of the chemical. Chemical disinfection, especially double-dose, can cause an unpleasant taste of water. The taste problem can be eliminated by using the right chemical and aeration.Positive aspects: these products are simple and safe to use and the use of the chemical has a residual effect, which gives some protection against contamination after treatment. Negative aspects: these products are not something we have in the house and we can react urgently, and chemical disinfection will not release all the germs that cause the disease. The water should be filtered before using chemical disinfection to ensure that all risks are eliminated.

\section{Purification by sedimention}

If the water is trubid, by giving the matter time to settle, it will make the water clear. Straining water through a cloth can make this process even more efficient. Water that has been purified by sedimentation is not clean. It still needs disinfection to remove the germs that cause the disease. In this way, both suspended solids and some of the pathogens will settle to the bottom of the vessel, eliminating the additional risk.Staying for two days further reduces contamination and also reduces the number of organisms that can lead to disease. This method is cheap and easy to use, but it does not completely remove the microbes that cause the disease. This method should be combined with some of the disinfection methods.

\section{Filtration}

Filters remove dirt from the water by physically blocking them and letting water flow through them. Water passes through material such as sand or ceramics, and harmful material remains "caught" in the filter. Filters are not usually used in emergencies. They will only be presented and briefly described here.

"Candle" filters, or ceramic filters are made of ceramics. The water is poured into one container and slowly passes through the ceramic into another container. The filter is cleaned with a brush, whenever it starts to clog and when the flow between the containers becomes slow. If possible, the filter should boil and kill disease-causing microbes that are "caught" in the 
filter.Another type of filter is sand filters: sand filtration is a quick and easy pre-cleaning option that reduces the amount of dirt in the water and makes disinfection more efficient. Users pour water from one container over a container of sand and gravel and an opening or rod. Then the water flows into the storage container.

All these efforts to purify the water are meaningless, if the water is not disinfected and properly stored after purification. The storage and use of treated water is just as important as the treatment process. Water should be stored in clean, covered containers (balloons, containers, tanks, tubs, barrels, water canisters, water storage containers) and stored in a cool, dark place.Contamination can also occur when water is removed from the containers in which it is stored. Hands and utensils can come into contact with water, so those who handle water must wash their hands with soap before handling drinking water.

\section{Conclusion}

Water supply is a function of general logistics, which is realized through organized activities of administrative and executive bodies. The planned use of springs and facilities for water supply on the territory ensures timely and uninterrupted supply of the Army and other users of logistics services on a territorial basis, with the necessary quantities of water necessary for the execution of missions, life and work of military units.

Water supply is a continuous process that is improved, supplemented and harmonized with the conditions for implementation.Providing the necessary quantities of hygienically correct water is one of the most important hygienicprophylactic measures in the protection and improvement of health, raising the psychophysical condition and combat ability of members of the Serbian Army.

In extraordinary circumstances, the provision of water due to possible damage or destruction of water supply facilities, primarily water supply, contamination of springs and an increase in the number of users, is a major problem. In order to overcome this problem, the units plan and organize the supply of drinking water and other needs.

Planning solves the problem of optimal allocation of resources for water purification and distribution, sets the information basis for its provision by quantity, quality and deadlines, and determines: who, what, when, where, how and why to do something in the future.

By organizing, activities are grouped and delegated to individual executors. The Serbian Army is also conditioned by outdated and defective equipment 
for water purification, which it has not renewed since its establishment until today, due to the restrictive financing of the Army.

Unlike regular conditions, in which difficulties with water supply occur only in exceptional situations and sometimes in waterless areas, during floods, usually, a very common and very complex problem, which to a greater or lesser extent affects combat readiness, because water is necessary for the normal functioning of the human body, and thus the unit.

Having that in mind, it is necessary to undertake preparations in regular conditions, both in terms of landscaping and construction of new facilities for water supply, and filling the units with modern means for obtaining, purifying, receiving, storing and distributing water. In that sense, after the flood, in cooperation with civilian capacities, microbiological and physicochemical analysis of drinking water is done, because the only way to determine whether drinking water is of appropriate quality is to sample water and perform water analysis, to determine health. the correctness of drinking water.Since our time and economic resources are limited in the first moments of the accident, it is not possible to monitor all parameters, but the most important ones are monitored: $\mathrm{pH}$ value, amount of residual chlorine, color, turbidity and the presence of pathogenic organisms. The limit values of all these parameters in our country are prescribed by the Rulebook on the hygienic safety of drinking water.If the values are exceeded, it is necessary to treat the water, in order to make it safe to drink. It is desirable to do a centralized water treatment as soon as possible, but we often do not have the money and time for it, so it is important that the population is familiar with the methods of water purification that they can apply at home.Water treatment at the place of use (in the household) in relation to the centralized one has certain advantages and disadvantages, it is much faster and cheaper, which is important in the first moments. However, unlike centralized treatment, it is much more difficult to control. Another disadvantage of these methods is that they remove physical and microbiological pollution, but not chemical contamination.

The article deals with three methods that are most often used in domestic water purification: disinfection, filtration and sedimentation.Filtration, as one of the common methods for water treatment, is not efficient and effective for implementation at home with the use of auxiliary hand tools. Which of these methods we apply depends on the location of the accident, the type of emergency and the general environmental conditions. 


\section{Literature}

1. Borislav Seman, „Voda u opštenarodnoj odbrani“, Vojnoizdavački i novinski centar, Beograd, 1987.

2. Dragan Marinović i dr, "Kvalitet vode za piće iz seoskih vodovoda posle majskih poplava 2014. godine u okolini grada Kraljeva", Tehnika, Beogard, br. 1/16, 2016, str. 167-171.

3. Marko Manojlović, Srbobran Đorđević, Svetozar Đorelijevski, Tihomir Rašić, "Higijena i tehnologija vode za piće", Udruženje za tehnologiju vode, Beograd, 1978.

4. Pravilnik o higijenskoj ispravnosti vode za piće, Službeni list SRJ, br.42/98, Beograd, 1998.

5. 5. Roger Bates, "Determination of $\mathrm{pH}$; theory and practice", Wiley, New York, 1973.

6. Sam Kayaga, Bob Reed, "Emergency treatment of drinking/water at the point use", WHO, Geneva, 2013. Dostupno na: https://www.who.int/water_sanitation_health/emergencies/WHO_TN_05 _Emergency_treatment_of_drinking_water_at_the_point_of_use.pdf?ua= 1

7. Srđan Novaković, Uroš Domazet, „Obezbeđenje vodom“, Generalštab Vojske Srbije i Crne Gore, Uprava za školstvo i obuku, Vojna akademija, Beograd, 2003.

8. Suvada Jusić, „Novi pristupi modeliranju pripreme vode za piće“, Vodoprivreda, br. 284/48, str. 191-201, 2016.

9. Tanja Knežević, Tatjana Illć, „Voda za piće - zdravstveni aspekt “, Savezni Zavod za zaštitu i unapređenje zdravlja, Beograd, 2000.

10. The International Federation of Red Cross and Red Crescent Societies (IFRC), "Household water treatment and safe storage in emergencies", IFRC, Geneva, 2008. Dostupno na: https://www.ifrc.org/Global/Publications/disasters/142100-hwt-en.pdf

11. United States Environmental Protection Agency (EPA), "Secondary Drinking Water Standards: Guidance for Nuisance Chemicals", EPA, Washington,2019. Dostupno na: https://www.epa.gov/dwstandardsregulations/secondary-drinking-waterstandards-guidance-nuisance-chemicals

12. Filip Trajković i dr, "Određivanje hemijskih pokazatelja kvaliteta površinskih voda u uzorcima Save, Dunava i Topčiderske reke", Medicinski podmladak, Beograd, br. 3/67, 2016, str. 81-87.

13. Željka Ostojić, Dušan Prodanović, Sanja Marčeta, „Korelacionoregresiona analiza modelirane prostorne raspodele reziduala hlora $\mathrm{u}$ vodovodnoj mreži“, Zaštita materijala, Beograd, br. 2/55, str. 173-180, 2014. 
14. World Health Organization (WHO), „Guidelines for drinking-water quality. 4th edition, incorporating the 1st addendum", WHO, Geneva, 2017. Dostupno

na: http://apps.who.int/iris/bitstream/handle/10665/254637/9789241549950eng.pdf;jsessionid=F1299C6391F71D5FFB876434C28B9304? sequence= 1

\title{
MONITORING KVALITETA VODE NAKON POPLAVA
}

\section{Nemanja Kneževićc ${ }^{13}$, Srboljub Nikolic ${ }^{14}$}

\begin{abstract}
Rezime
Bezbedna voda za piće je jedan od najvažnijih uslova zdravog života. Međutim, u slučaju katastrofa $i$ vanrednih situacija voda često biva zagađena raznim primesama fizičkog, hemijskog i/ili biološkog porekla. Ova zagađenja mogu dovesti do brojnih zdravstvenih problema, uključujući $i$ razne zarazne bolesti. Iz tog razloga je važno delovati preventivno, i pravovremeno $i$ hitno izvršiti odgovarajući tretman i prečišćavanje vode, $u$ zavisnosti od vrste zagađenja. Da bi se utvrdila vrsta zagađenja i izvršio odgovrajući tretman vode, preduslov je da se urade određene hemijske analize $i$ monitoring kvaliteta vode kroz praćenje parametara kvaliteta vode. Budući da su nam i vremenski i ekonomski resursi ograničeni u prvim momentima nesreće, nije moguće pratiti sve parametre, već se prate oni najvažniji: pH vrednost, količina rezidualnog hlora, boja, turbiditet i prisustvo patogenih organizama. Međutim, $i$ kada se utvrdi vrsta zagađenja, nekada nije moguće odmah uraditi centralizovano prečišćavanje vode, zato je važno da budemo upoznati sa metodama koje možemo samostalno, i uz pomoć nekih priručnih sredstava, da primenimo u svom domaćinstvu (npr. dezinfekcija proključavanjem vode ili upotrebom neke od hemikalija za dezinfekciju; taloženjem i sl). Uz pomoć ovih metoda može se obezbediti barem fiiološki minimum za članove porodice $u$ prvim momentima nakon nesreće, dok se ne izvrši centralizovano prečišćavanje.
\end{abstract}

Ključne reči: voda, zagađenje vode, poplave, monitoring, tretman vode

Datum dolaska (Date received): 22.12.2020.

Datum prihvatanja (Date accepted): 15.05.2021.

${ }^{13}$ Nemanja Knežević, M.A. Poljoprivredni fakultet, Univerzitet u Beogradu, R. Srbija 14 dr Srboljub Nikolić, docent, Vojna akademija, Univerzitet odbrane, Beograd, R. Srbija, e-mail: srboljub.nikolic@yahoo.com 